\title{
Activity Profiles of Cholinergic and Intermingled GABAergic and Putative Glutamatergic Neurons in the Pontomesencephalic Tegmentum of Urethane-Anesthetized Rats
}

\author{
Soufiane Boucetta and Barbara E. Jones \\ Department of Neurology and Neurosurgery, Montreal Neurological Institute, McGill University, Montreal, Quebec, Canada H3A 2B4
}

Cholinergic neurons in the pontomesencephalic tegmentum form part of the ascending activating system and are thought to participate in stimulating cortical activation. Yet in the laterodorsal tegmental and pedunculopontine tegmental nuclei (LDT and PPT), they lie intermingled with GABAergic and glutamatergic neurons, which could also modulate cortical activity and sleep-wake state. To characterize the discharge of these cell types in relation to cortical activity, we recorded neurons in urethane-anesthetized rats during spontaneous slow wave and somatosensory evoked fast electroencephalographic (EEG) activity, then labeled the cells by juxtacellular technique with Neurobiotin $(\mathrm{Nb})$ and dual-immunostained them for vesicular acetylcholine transporter (VAChT) and glutamic acid decarboxylase (GAD). All cholinergic cells discharged minimally during prestimulation $(\sim 0.5 \mathrm{~Hz})$ and moderately in a tonic manner $(\sim 4 \mathrm{~Hz})$ during stimulation. Being heterogeneous, some GABAergic, called "On," cells $(\sim 48 \%)$ increased their discharge (from $\sim 4$ to $7 \mathrm{~Hz})$, whereas others, called "Off” cells ( $\sim 38 \%)$, decreased or ceased firing during stimulation. Similarly, some noncholinergic/non-GABAergic On cells increased (from $\sim 2$ to $6 \mathrm{~Hz}, \sim 49 \%$ ), whereas other Off cells decreased firing $(\sim 35 \%)$ during stimulation. Putative glutamatergic On together with GABAergic On neurons could thus act in parallel with cholinergic cells to stimulate cortical activation. Possibly influenced by cholinergic On and glutamatergic Off cells, whose change in discharge precedes theirs, the GABAergic Off cells could oppose neighboring neurons such as noradrenergic cells, which discharge during waking and cease firing during sleep. By concerted activity, these heterogeneous cell groups can modulate cortical activity and behavioral state across the sleep-waking cycle.

\section{Introduction}

The cholinergic neurons in the brainstem, which form an important part of the ascending activating system, are clustered in the pontomesencephalic tegmentum within the laterodorsal tegmental (LDT) and the pedunculopontine tegmental (PPT) nuclei (Jones, 1993; Steriade, 2004). These neurons project rostrally along with other reticular neurons into the thalamus, the lateral hypothalamus, and basal forebrain, where neurons in turn give rise to widespread cortical projections and stimulate cortical activation (Mesulam et al., 1983; Jones and Yang, 1985; Hallanger et al., 1987; Paré et al., 1988). The cholinergic cells also project into the pontine reticular formation, where neurons in turn promote muscle atonia together with cortical activation and the state of rapid eye movement (REM) sleep or as it is also called, paradoxical sleep (PS) (Mitani et al., 1988; Jones, 1990, 2004; Semba et al., 1990). Evidence from pharmacological and lesion studies indi-

Received Nov. 14, 2008; revised March 9, 2009; accepted March 12, 2009.

This work was supported by the Canadian Institutes of Health Research (Grants MOP-13458 and MOP-82762). We thank Lynda Mainville for her technical assistance in immunohistochemistry, Frederic Brischoux for his consultation in neuroanatomy, Chris Cordova for his help in data analysis, and Oum Hassani for her assistance with the electrophysiology.

Correspondence should be addressed to Dr. Barbara E. Jones, Montreal Neurological Institute, McGill University, 3801 University Street, Montreal, Quebec, Canada H3A 2B4. E-mail: barbara.jones@mcgill.ca.

DOI:10.1523/JNEUROSCI.5502-08.2009

Copyright $\odot 2009$ Society for Neuroscience $\quad$ 0270-6474/09/294664-11\$15.00/0 cates that the cholinergic neurons play an important role in stimulating cortical activation during waking and PS and also in triggering the state of PS (Karczmar et al., 1970; Amatruda et al., 1975; Gillin and Sitaram, 1984; Webster and Jones, 1988). Single unit recording studies in the LDT and PPT nuclei of cats or rats identified cells which were presumed to be cholinergic and fired in association with cortical activation during waking and PS or more selectively during PS (el Mansari et al., 1989; Steriade et al., 1990a; Steriade et al., 1990b; Kayama et al., 1992). Yet, the cholinergic neurons in the pontomesencephalic tegmentum are intermingled with other noncholinergic neurons, including GABAergic neurons (Ford et al., 1995), which might also participate in different ways in the modulation of cortical activity and sleep-wake state (Maloney et al., 1999). Most recently, evidence for the presence of glutamatergic in addition to GABAergic and cholinergic neurons in the LDT and PPT nuclei was also presented (Wang and Morales, 2009). To understand the role of the cholinergic, GABAergic, and putative glutamatergic neurons of this region, it is thus necessary to identify recorded neurons according to their neurotransmitter phenotype.

We applied the technique of juxtacellular labeling of recorded neurons for subsequent immunohistochemical identification of cholinergic, GABAergic, and putative glutamatergic neurons in the LDT, SubLDT, and medial PPT (MPPT). As previously used 
for identification of the cholinergic and other neurons in the basal forebrain (Manns et al., 2000a,b; Manns et al., 2003), we labeled recorded cells with Neurobiotin ( $\mathrm{Nb}$ ) following their characterization in relation to cortical activity in urethaneanesthetized rats. As possible with this anesthesia, somatic stimulation was used to evoke enhanced fast, beta-gamma along with rhythmic slow, theta-like activity, which resembles cortical activation, from a baseline of irregular slow activity, which resembles slow-wave activity of natural slow-wave sleep (SWS) (Maloney et al., 1997; Clement et al., 2008). Similar to comparable populations of cells in the basal forebrain, the cell groups were found to be heterogeneous in their properties and their response to stimulation with associated cortical activation.

\section{Materials and Methods}

Animals and surgery. Experiments were performed on 66 adult male Long-Evans rats (200-250 g; Charles River). All procedures were approved by the McGill University Animal Care Committee and the Canadian Council on Animal Care. The animals were anesthetized with urethane (ethyl carbamate, Sigma) using an initial dose $1.4 \mathrm{~g} / \mathrm{kg}$ (i.p.) and supplementary doses if necessary of $0.1-0.15 \mathrm{~g} / \mathrm{kg}$ (i.p.) to insure an adequate level of anesthesia, as determined by the lack of response to pinching of the hind limb. Body temperature was maintained at $36-37^{\circ} \mathrm{C}$ by a thermostatically controlled heating pad. The anesthetized animals were positioned in a stereotaxic apparatus (David Kopf Instruments) for both the surgery and subsequent recording. For EEG recording, stainless steel screws were placed over the retrosplenial cortex [anteroposterior (AP) $-4.0 \mathrm{~mm}$, lateral (L) $\pm 0.5 \mathrm{~mm}$ relative to bregma] and in the frontal bone as a reference.

Unit recording and labeling. As described previously (Manns et al., 2000a), juxtacellular recording and labeling was performed using an intracellular amplifier (IR-283, Neurodata Instruments). Unit recordings were performed with glass microelectrodes $(\sim 0.5-1.5 \mu \mathrm{m}$ tip and $\sim 25-40 \mathrm{M} \Omega$ ) filled with $0.5 \mathrm{M} \mathrm{NaCl}$ and 5.0\% Neurobiotin (Nb, Vector Laboratories). To reach the pontomesencephalic tegmentum, holes were drilled in the skull ( $\mathrm{AP}-5.0 \mathrm{~mm}$ from bregma, $\mathrm{L} \pm 0.9 \mathrm{~mm}$ ) and after opening the dura, the electrode descended from anterior to posterior at an angle of $30^{\circ}$ from the vertical, so as to avoid the tentorium. Single units were then isolated as the electrode was descended through the pontomesencephalic tegmentum into the region of the LDT. Once isolated, the unit was characterized during spontaneous irregular slow EEG activity and during somatosensory stimulation. The somatic stimulation consisted of a continuous pinch of the tail applied by large, blunt forceps such as to apply pressure but not to evoke pain. The stimulation was repeated several times to confirm that the response was constant. After the recording and characterization of isolated neurons, they were labeled by applying the juxtacellular method, as originally developed and described by Pinault (1996). Labeling was accomplished by modulating the firing of the cell through positive current pulses (1-10 nA) for a period of 2-10 min. In this study, for a total of 149 units submitted to this juxtacellular labeling protocol in 66 rats, 118 units were successfully labeled with $\mathrm{Nb}(\sim 80 \%)$.

Within a few hours after the juxtacellular labeling, the animals were administered an overdose of urethane and perfused transcardially with physiological saline $(0.9 \% \mathrm{NaCl})$, followed by $500 \mathrm{ml}$ of a fixative containing $3 \%$ paraformaldehyde in $0.1 \mathrm{~m}$ phosphate buffer, $\mathrm{pH}$ 7.4. The brains were removed, postfixed overnight in the fixative solution, and immersed for $2 \mathrm{~d}$ in $30 \%$ sucrose in phosphate buffer for cryoprotection. They were frozen at $-50^{\circ} \mathrm{C}$ and stored at $-80^{\circ} \mathrm{C}$.

Histochemistry. Serial sections were cut at $25 \mu \mathrm{m}$ thickness in the coronal plane on a freezing microtome and collected for histochemical processing. For revelation of $\mathrm{Nb}$, sections were incubated for $2.5 \mathrm{~h}$ in Cy2-conjugated streptavidin (1:1000, Jackson ImmunoResearch Laboratories). Following location of an $\mathrm{Nb}$-labeled cell, the relevant section was dual-immunostained for vesicular transporter protein for acetylcholine [VAChT, with a goat $(\mathrm{Gt})$ polyclonal antibody, AB1578 from Millipore Bioscience Research Reagents and a Cy5-conjugated donkey (Dky) anti-Gt antibody from Jackson Immu-
noResearch Laboratories] and glutamic acid decarboxylase [GAD, with a mouse (Ms) monoclonal anti-GAD67 antibody, MAB5406 from Millipore Bioscience Research Reagents and a Cy3-conjugated Dky anti-Ms antibody from Jackson ImmunoResearch Laboratories] for identification of cells as cholinergic, GABAergic, or noncholinergic-non-GABAergic. Sections were viewed and images acquired by epi-fluorescence using a Nikon Eclipse E800 (Nikon Instruments) equipped with a digital camera (Microfire S99808, Optronics). The labeled cells were mapped onto a computer resident atlas with the aid of Neurolucida (v7, MicroBrightField). Cell size was measured by the long axis of the cell and cells classified as small ( $\leq 15 \mu \mathrm{m})$ or mediumto-large $(16-35 \mu \mathrm{m})$. Of $118 \mathrm{Nb}$-labeled cells, 73 were judged unequivocally positively (by bright fluorescence in soma, “+”) immunostained or negatively (by no fluorescence in soma, “-”) immunostained for VAChT and GAD and were located within the confines of the LDT, SubLDT, or adjacent MPPT, so as to be included and reported in Results.

Data analysis. Analysis of physiological data was performed on 40 s periods corresponding to prestimulation, stimulation, and poststimulation conditions. For the EEG, spectral analysis was performed to determine the dominant peak frequency and integrated power of the spectra in the slow, delta $(0.5-4.5 \mathrm{~Hz})$ and fast high beta-gamma $(20-60 \mathrm{~Hz})$ frequencies. As established previously (Manns et al., 2000a), somatic stimulation resulted in a change in the EEG from a predominantly slow, irregular delta-like pattern to a faster rhythmic theta-like pattern and increased fast high beta-gamma activity, typical of a degree of cortical activation despite a lack of behavioral response in the urethane-anesthetized animal (see supplemental Fig. 1, available at www.jneurosci.org as supplemental material).

Spike duration was determined from all spikes averaged across the prestimulation period for each unit. The duration was measured at the first and second zero crossings and thus from the initial positive to the negative deflection and to the subsequent return to resting level (measured with an offset from resting corresponding to $10 \%$ of the positive peak amplitude so as to avoid variations in baseline zero) (see supplemental Fig. $2 A$, available at www.jneurosci.org as supplemental material). For unit discharge, average discharge rate (ADR) was calculated as spikes/s per condition, and instantaneous firing frequency (IFF) as the corresponding frequency of the primary mode of the interspike interval (ISI) histogram per condition (see supplemental Fig. $2 B, C$, available at www.jneurosci.org as supplemental material). Using the condition during which a unit discharged maximally, each unit was classified according to several characteristics of its discharge. First, it was classified according to the IFF as "fast" $(>14.5 \mathrm{~Hz})$, "slow" $(0.25-14 \mathrm{~Hz})$, "very slow" $(<0.25$ $\mathrm{Hz})$, or "silent" $(0 \mathrm{~Hz})$. Second, each unit was classified as "tonic" or "phasic" by comparing the IFF to the ADR, or specifically the corresponding interval of the ADR to the ISI distribution. If the ADR interval fell within $95 \%$ of the ISI distribution, the unit was classified as tonic, if outside $95 \%$, as phasic. Among the tonically firing units, their discharge was further distinguished as "tonic regular" if their ADR interval fell within $82 \%$ of the ISI distribution or as "tonic irregular" if outside $82 \%$. Among phasically firing units, their discharge was further distinguished according to the IFF as comprised by high-frequency spike bursts, as $>80$ $\mathrm{Hz}$, or lower frequency spike clusters, as $<80 \mathrm{~Hz}$. Finally, cells were classified according to their response to somatic stimulation as "On," if their ADR increased, "Off" if it decreased or "No" if it showed no change $(<1 \mathrm{~Hz})$. The discharge of units was further examined by autocorrelation histogram $(\mathrm{ACH})$ to determine whether it was rhythmic or not and by spike triggered averaging (STA) with EEG activity to determine whether it was cross-correlated with cortical activity (see supplemental Fig. 3, available at www.jneurosci.org as supplemental material).

All analyses of raw data were done using Matlab R2007a (MathWorks) and statistical analysis using Systat 11 (SPSS). Comparisons were made across cell types using $\chi^{2}$, ANOVA with Bonferroni adjustment for post hoc paired comparisons, Student's $t$ tests, and Kruskal-Wallis, MannWhitney or Wilcoxon nonparametric tests (for variables which contained zeros or were irregularly distributed). Figures were made using Adobe Photoshop CS (Adobe Systems) for photomicrographs and Adobe Illustrator Creative Suite (CS2, Adobe Systems) for electrophysiological data. 


\section{Results}

Of 149 cells, which were recorded, characterized, and submitted to juxtacellular labeling, 73 were successfully labeled with Neurobiotin $(\mathrm{Nb})$, could be judged unequivocally immunopositive or negative for VAChT and GAD and were located in the region of the pontomesencephalic cholinergic cell area, centered upon the LDT. The Nb-labeled cells were distributed through the caudal to rostral LDT $(n=$ 28 ) or its ventral extension beneath the central gray in the SubLDT $(n=25)$ or medial pedunculopontine tegmental nucleus (MPPT) $(n=20)$ (Fig. 1$)$. Of the $73 \mathrm{Nb}$ labeled cells, 11 were established as immunopositive for VAChT $(\mathrm{Nb}+/ \mathrm{VAChT}+), 29$ as immunopositive for $\mathrm{GAD}(\mathrm{Nb}+/$ $\mathrm{GAD}+$ ), and 33 as immunonegative for both VAChT and GAD (Nb+/VAChT-/ GAD-) (Table 1). The Nb-labeled cholinergic, GABAergic, and noncholinergic/nonGABAergic cells were codistributed through the LDT, SubLDT, and MPPT (Fig. 1, Table 1). Morphologically, the $\mathrm{Nb}+/$ $\mathrm{VAChT}+$ cells were in the vast majority polygonal and multipolar, whereas the $\mathrm{Nb}+/ \mathrm{GAD}+$ and the $\mathrm{Nb}+/ \mathrm{VAChT}-/$ $\mathrm{GAD}$ - cells were in the majority round, oval, or fusiform, accordingly bipolar and only in the minority polygonal and multipolar, thus differing significantly according to shape (Table 1). All the Nb-labeled cholinergic cells were medium-to-large cells, whereas the GABAergic and noncholinergic/ non-GABAergic cells were in large number small in addition to medium-to-large, thus differing significantly according to size (Table 1). This difference was reflected by a significant difference in the average (long axis) cell size among the cell groups, with the cholinergic cells being significantly larger on average than the GABAergic and noncholinergic/non-GABAergic cells (Table 2).

Physiologically, the Nb-labeled cells were heterogeneous in their discharge properties. They responded differentially to somatic stimulation and the evoked changes in EEG activity, which were characterized by a decrease in slow irregular, delta-like activity $(0.5-4 \mathrm{~Hz})$ and an increase in fast, high betagamma activity $(20-60 \mathrm{~Hz})$, sometimes riding upon rhythmic slow, theta-like activity (see supplemental Fig. 1, available at www.jneurosci.org as supplemental material) (Table 1). The cholinergic cells had on average longer duration spikes than the GABAergic and noncholinergic/non-GABAergic cells (see supplemental Fig. 2A, available at www.jneurosci.org as supplemental material) (Table 2). However, given large variability they could not be distinguished on an individual basis by this feature (see supplemental Fig. 4A, available at www.jneurosci.org as supple-


Figure 1. Distribution of recorded cells in the mesopontine tegmentum. The recorded, Nb-labeled cells were immunohistochemically identified as cholinergic, using VAChT (Nb+/VAChT +, blue circles), as GABAergic, using GAD (Nb $+/ G A D+$, red triangles), or as noncholinergic/non-GABAergic (Nb+/VAChT-/GAD-, green squares). GABAergic and noncholinergic/nonGABAergic cells were further distinguished according to their response as On (filled symbols), Off (open symbols), or No (small filled symbols) response to somatic stimulation. Cells are mapped onto appropriate levels (anterior, A0.9, A0.5, or A0.1 mm to interaural zero) through the LDT/SubLDT/MPPT cholinergic cell area. Recordings and images are presented for representative cells (largest symbols) of the cholinergic (Fig. 2), GABAergic On and Off (Figs. 3, 4), and noncholinergic/non-GABAergic On and Off cells (Figs. 5, 6). CG, Central gray; CnF, cuneiform nucleus; crf, central reticular fasciculus; DMT, dorsomedial tegmental area; DR, dorsal raphe nucleus; DT, dorsal tegmental nucleus; IC, inferior colliculus; LC, locus ceruleus; LL, lateral lemniscus; LPB, lateral parabrachial nucleus; LPPT, lateral pedunculopontine tegmental nucleus; Me5, mesencephalic trigeminal nucleus; mlf, medial longitudinal fasciculus; M05, motor trigeminal nucleus; MPB, medial parabrachial nucleus; PnC, pontine reticular nucleus, caudal part; $\mathrm{Pn} 0$, pontine reticular nucleus, oral part; $\mathrm{Pr} 5$, principal sensory trigeminal nucleus; $R$, raphe nuclei; $\mathrm{Rt} T$, reticulotegmental nucleus of the thalamus; scp, superior cerebellar peduncle; SubC, subceruleus; VT, ventral tegmental nucleus.

mental material). According to their instantaneous firing frequency (calculated from the modal value of the interspike interval) during somatic stimulation, the majority of all cells were slow firing $(0.25-$ $14.5 \mathrm{~Hz}$ ), regardless of cell type (see supplemental Fig. 2C, available at www.jneurosci.org as supplemental material) (Table 1). The cell groups could thus not be clearly distinguished according to average 
Table 1. Frequency of cholinergic, GABAergic, and noncholinergic/non-GABAergic cells with different anatomical and physiological characteristics ${ }^{a}$

\begin{tabular}{|c|c|c|c|c|c|}
\hline & All cells & $\mathrm{Nb}+/ \mathrm{VAChT}+$ & $\mathrm{Nb}+/ \mathrm{GAD}+$ & $\mathrm{Nb}+/ \mathrm{NAChT}-/ \mathrm{GAD}-$ & $\chi^{2}$ statistic $(\mathrm{df})$ \\
\hline Total & 73 & 11 & 29 & 33 & \\
\hline \multicolumn{6}{|l|}{ Anatomy } \\
\hline Area & & & & & $7.58(4)$ \\
\hline LDT & 28 & 7 & 7 & 14 & \\
\hline SubLDT & 25 & 3 & 10 & 12 & \\
\hline MPPT & 20 & 1 & 12 & 7 & \\
\hline Shape ${ }^{b}$ & & & & & $6.76(2)^{*}$ \\
\hline Round-oval-fusiform & 36 & 2 & 18 & 16 & \\
\hline Polygonal & 33 & 9 & 10 & 14 & \\
\hline $\operatorname{Size}^{b}$ & & & & & $7.03(2)^{*}$ \\
\hline Small $(\leq 15 \mu \mathrm{m})$ & 24 & 0 & 12 & 12 & \\
\hline Medium-large $(>15 \mu \mathrm{m})$ & 45 & 11 & 16 & 18 & \\
\hline \multicolumn{6}{|l|}{ Physiology } \\
\hline Frequency (stimulation) $^{c}$ & & & & & $5.35(6)$ \\
\hline Fast $(>14.5 \mathrm{~Hz})$ & 12 & 1 & 6 & 5 & \\
\hline Slow $(<14.5 \mathrm{~Hz})$ & 50 & 10 & 19 & 21 & \\
\hline Very slow $(<0.25 \mathrm{~Hz})$ & 6 & 0 & 3 & 3 & \\
\hline Silent $(0 \mathrm{~Hz})$ & 5 & 0 & 1 & 4 & \\
\hline Firing type (stimulation) ${ }^{d}$ & & & & & $3.27(4)$ \\
\hline Tonic regular & 29 & 6 & 11 & 12 & \\
\hline Tonic irregular & 22 & 5 & 9 & 8 & \\
\hline Phasic cluster & 12 & 0 & 6 & 6 & \\
\hline Phasic burst & 0 & 0 & 0 & 0 & \\
\hline \multicolumn{6}{|l|}{ Response to stimulation } \\
\hline Increase (0n) & 41 & 11 & 14 & 16 & $10.14(4)^{*}$ \\
\hline Decrease (0ff) & 23 & 0 & 11 & 12 & \\
\hline No change (No) & 9 & 0 & 4 & 5 & \\
\hline
\end{tabular}

${ }^{a}$ Frequency (number of cells) for the three groups are presented and compared, using the likelihood ratio $\chi^{2}$ statistic; ${ }^{*} p<0.05 ;{ }^{* *} p<0.01 ;{ }^{* * *} p<0.001$.

${ }^{b}$ Shape and size (long axis) of whole cell bodies only $(n=69)$.

'According to instantaneous firing frequency calculated from interspike interval modal value during stimulation.

${ }^{d}$ Including cells with discharge rates $>0.25 \mathrm{~Hz}(n=63)$.

Table 2. Morphological and physiological measures of cholinergic, GABAergic, and noncholinergic/non-GABAergic cell groups

\begin{tabular}{lclll}
\hline & $\mathrm{Nb}+/ \mathrm{NAChT}+{ }^{a}$ & $\mathrm{Nb}+/ \mathrm{GAD}+{ }^{b}$ & $\mathrm{Nb}+/ \mathrm{NAChT}-/ \mathrm{GAD}-^{c}$ & Cell group statistic \\
\hline $\begin{array}{l}\text { Morphology } \\
\quad \text { Size }(\mu \mathrm{M})^{d}\end{array}$ & $24.32 \pm 2.50(11)^{b, c}$ & $16.34 \pm 0.87(28)^{a}$ & $17.42 \pm 1.19(30)^{a}$ & $4.96(2,65)^{* *}$ \\
$\begin{array}{l}\text { Physiology } \\
\quad \text { Spike width 1 (ms) }\end{array}$ & $0.55 \pm 0.04(11)^{b}$ & $0.42 \pm 0.02(29)^{a}$ & $0.45 \pm 0.02(33)$ & $4.91(2,70)^{* *}$ \\
$\quad$ Spike width 2 (ms) & $1.71 \pm 0.17(11)^{b, c}$ & $1.22 \pm 0.06(29)^{a}$ & $1.29 \pm 0.08(33)^{a}$ & $5.26(2,70)^{* *}$
\end{tabular}

Mean \pm SEM values (with number of cells) are presented and compared by one-way ANOVA $[F(\mathrm{df})]$, with main effect of cell group indicated by ${ }^{* *}(p<0.01)$.

$a-c$ Post-hoc Bonferroni-corrected pairwise differences in means are indicated between groups by corresponding letters.

${ }^{d}$ According to long axis of cell body measured in whole cells $(n=69)$.

${ }^{e}$ Measured at base of first zero crossing.

${ }^{f}$ Measured at base of second zero crossing.

discharge rate or instantaneous firing frequency during stimulation (supplemental Fig. 4B, $C$, available at www.jneurosci.org as supplemental material). Nonetheless, the GABAergic and noncholinergic/ non-GABAergic cells were more heterogeneous than the cholinergic cells and included a significant number of fast firing $(>14.5 \mathrm{~Hz})$ neurons along with very slow firing $(<0.25 \mathrm{~Hz})$ and silent neurons in the stimulation condition. According to their firing pattern (assessed from the interspike interval histograms) during stimulation, the vast majority of all cells were tonic and regular or irregular, regardless of cell type (Table 1). In contrast to cholinergic cells, GABAergic and noncholinergic/non-GABAergic cells also included neurons which discharged in a phasic manner, characterized by clusters of spikes $(<80 \mathrm{~Hz}$ instantaneous firing frequency within the cluster). No cells discharged in high frequency bursts $(>80 \mathrm{~Hz}$ instantaneous firing frequency). No cholinergic and few of the noncholinergic cells showed rhythmic firing that was cross-correlated with the EEG ac- tivity $(n=3)$ in either prestimulation or stimulation conditions (see supplemental Fig. 3, available at www.jneurosci.org as supplemental material). Classified according to their response to somatic stimulation as On if they increased, Off if they decreased and No if they showed no change in their rate of discharge, the three cell groups differed significantly (Table 1). Whereas all cholinergic cells were On, the GABAergic and noncholinergic/non-GABAergic cells comprised On, Off, and No cells (Table 1).

Given the heterogeneity of the noncholinergic cells, their further study was performed according to the functional subgroups of On, Off, or No. The On and Off $\mathrm{Nb}+/ \mathrm{GAD}+$ and $\mathrm{Nb}+/$ VAChT $-/ G A D-$ cell groups were further examined in detail and compared with the $\mathrm{On} \mathrm{Nb}+/ \mathrm{VAChT}+$ cells (Table 3 ). As will be presented below for each of these cell types, despite differing degrees of variation in discharge properties, the GABAergic and noncholinergic/nonGABAergic On cells behaved in a similar manner to the cholinergic cells. Moreover, the overlap in electrophysiological properties of the three On cell groups was such that a single cell could not be distinguished as cholinergic, GABAergic, or noncholinergic/non-GABAergic according to those properties (see supplemental Fig. 5, available at www. jneurosci.org as supplemental material). Off cells behaved in an opposite manner to the cholinergic and other On cells in their response to stimulation and relationship to EEG activity. As for the On cells, the overlap in their electrophysiological properties did not allow any single cell to be distinguished as GABAergic or non-GABAergic according to those properties (see supplemental Fig. 6, available at www.jneurosci.org as supplemental material).

Cholinergic $(\mathrm{Nb}+/ \mathrm{VAChT}+)$ neurons

$\mathrm{Nb}$-labeled cholinergic cells $(n=11)$ represented a relatively homogeneous group according to both morphological and physiological characteristics (Table 1). They were commonly polygonal, multipolar, and medium-to-large in size (mean \pm SEM: $24.32 \pm 2.50 \mu \mathrm{m}$ in long diameter) (Table 2, Fig. $2 A$ ). They had on average a relatively long spike duration (see Fig. $2 C$; supplemental Fig. $2 A$, available at www.jneurosci.org as supplemental material) $(0.55 \pm 0.04 \mathrm{~ms}$ mean duration to first zero crossing and $1.71 \pm 0.17 \mathrm{~ms}$ duration to second zero crossing) (Table 2), yet comprised cells with short as well as long duration spikes (supplemental Fig. $4 A$, available at www.jneurosci.org as supplemental material). In absence of stimulation, they fired minimally in association with the irregular slow EEG activity during the prestimulation period (Fig. $2 B, C$ ). They greatly increased their firing during somatic stimulation and the associated increase in fast cortical activity. Following cessation of the stimulation (Post), the cholinergic cells slowed and often subsequently ceased firing (Fig. 2B,C). Across 
Table 3. Average discharge rate and instantaneous firing frequency during prestimulation and stimulation conditions of cholinergic, GABAergic, and noncholinergic/nonGABAergic cell groups

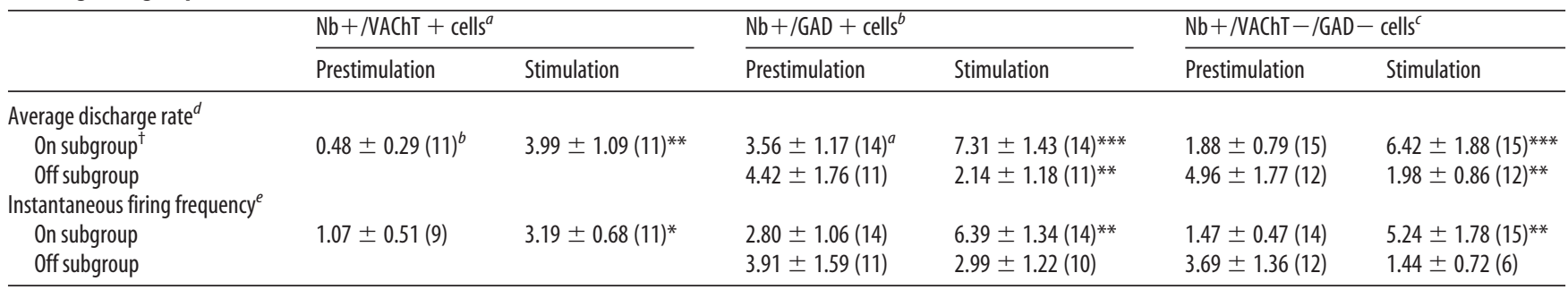

Mean \pm SEM values (with number of cells) of average discharge rate and instantaneous firing frequency are presented and compared between the prestimulation and stimulation conditions by nonparametric Wilcoxon tests for each cell subgroup $\left({ }^{*} p<0.05 ;{ }^{* *} p<0.01 ;{ }^{* * *} p<0.001\right)$. Rates and frequencies were compared among cell groups for the prestimulation and stimulation conditions by nonparametric Kruskal-Wallis tests. A main effect of cell group was significant only for the average discharge rate during prestimulation among the 0 subgroups $\left({ }^{\dagger} p<0.05\right)$.

${ }^{a-c}$ According to post-hoc Mann-Whitney ( $p<0.017$, allowing 3 comparisons), pairwise differences in means are indicated between groups by corresponding letters.

${ }^{d}$ Average discharge rate $(\mathrm{Hz})$ calculated for $\sim 40$ s periods of each condition.

${ }^{e}$ Instantaneous firing frequency $(\mathrm{Hz})$ calculated from the interspike interval modal value for $\sim 40$ s periods having $>2$ spikes.

cells, the average discharge rate increased significantly during stimulation $(3.99 \pm 1.09$ $\mathrm{Hz}$ ) compared with the prestimulation pe$\operatorname{riod}(0.48 \pm 0.29 \mathrm{~Hz})$ (Table 3$)$ and the poststimulation period $(0.25 \pm 0.15 \mathrm{~Hz} ; p<$ 0.05). During stimulation, the cholinergic cell discharge was characterized by a regular (Fig. 2C) or irregular tonic firing pattern typified by a slow instantaneous firing frequency (mean $3.19 \pm 0.68 \mathrm{~Hz}$ ) (Table 3 ) that was similar to the average discharge rate (see supplemental Fig. $2 B, C$, available at www. jneurosci.org as supplemental material). Neither during stimulation or prestimulation was the discharge of the cells rhythmic or cross-correlated with slow EEG activity (see supplemental Fig. 3, available at www. jneurosci.org as supplemental material). At the beginning of somatic stimulation, the majority of cholinergic cells $(n=7)$ increased their firing before the change in EEG activity (by $\sim 180 \mathrm{~ms}$ for the cell shown in Fig. 2, up to $\sim 1.6 \mathrm{~s}$ across cells).

\section{GABAergic (Nb+/GAD+) neurons}

Based on their response to somatic stimulation, the Nb-labeled GABAergic neurons formed a heterogeneous group, the majority showing an increase, as On cells $(\sim 50 \%)$, some a decrease, as Off cells $(\sim 34 \%)$, and a small minority no change, as No cells $(\sim 16 \%)$ (Table 1$)$. These functionally different cell types were codistributed through the LDT, SubLDT, and MPPT. They did not differ significantly according to cell size or spike duration (data not shown).

$\mathrm{Nb}+/ \mathrm{GAD}+$ On cells

The GABAergic On cells $(n=14)$ were not homogeneous in their morphological or physiological properties. As for the total $\mathrm{Nb}+/ \mathrm{GAD}+$ cell group (Table 1), the On subgroup varied in size and shape, being either small ( $n=7$ ) (Fig. $3 A$ ) or mediumlarge $(n=7)$ and either bipolar $(n=8)$ (Fig. $3 A)$ or multipolar $(n=6)$. Similar to all GABAergic cells (Table 2), the On cells had a
- $\mathrm{Nb}+\mathrm{NAChT}+$ cell
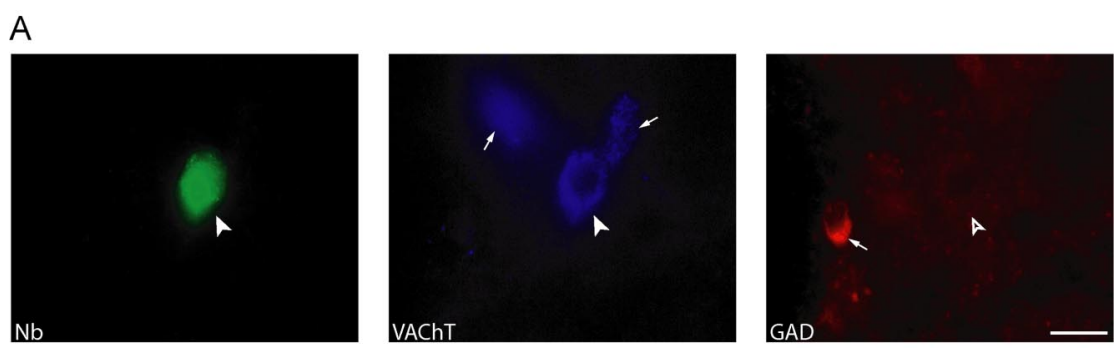

B

Pre

Somatic Stimulation

Post
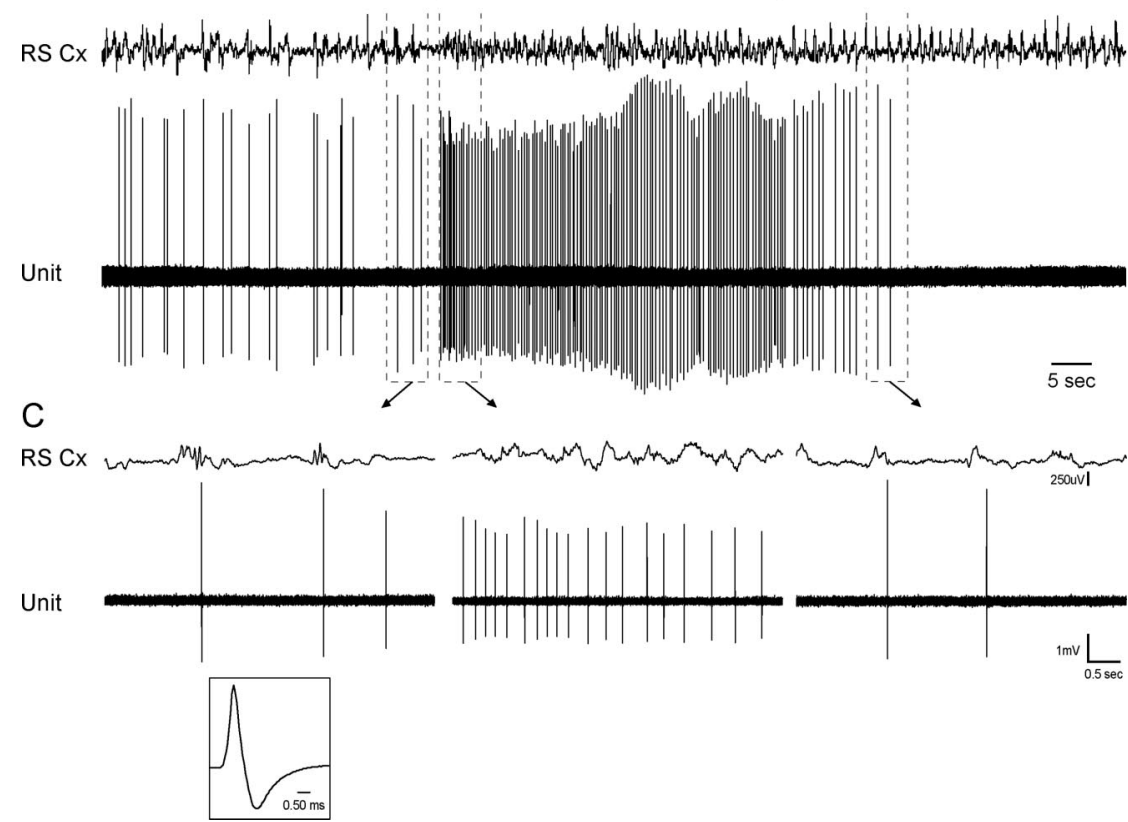

Figure 2. $\mathrm{Nb}+/ \mathrm{NAChT}+$ cell. $A$, The Nb-labeled cell (filled arrowhead, \#ABS80a) was positively immunostained for VAChT (filled arrowhead) and negatively for GAD (open arrowhead), while near other VAChT + and GAD + cells in the region (small arrows). Scale bar, $20 \mu \mathrm{m}$. The cell was located in the SubLDT (largest blue circle) (Fig. 1, A0.5). B, C, The unit discharged at an average low rate $(0.70 \mathrm{~Hz}$ ) in association with spontaneous irregular slow-wave activity on the EEG of the retrosplenial cortex (RS $\mathrm{CX}$ ) in the period preceding stimulation (Pre). It increased its rate markedly (to $3.10 \mathrm{~Hz}$ ) and fired tonically during somatic stimulation in association with faster activity on the EEG. (See also supplemental Figs. 2, 3, available at www.jneurosci.org as supplemental material.) Note that the increase in unit discharge preceded the change in EEG activity (by $\sim 180 \mathrm{~ms}$ ). After stimulation (Post), the unit initially decreased then ceased firing as the EEG returned to irregular slow-wave activity. Traces in $\boldsymbol{B}$ (enclosed by dashed lines) are expanded in C (arrows). The unit had a relatively long duration spike (shown in C, 0.76 and $2.55 \mathrm{~ms}$ at first and second zero crossings) (supplemental Fig. 2, available at www.jneurosci.org as supplemental material). 
$\Delta \mathrm{Nb}+/ \mathrm{GAD}+$ "On" cell

A
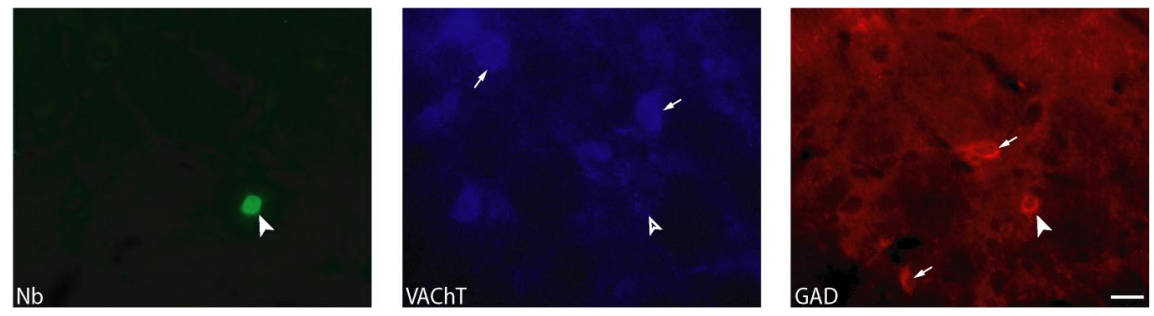

B Pre Somatic Stimulation

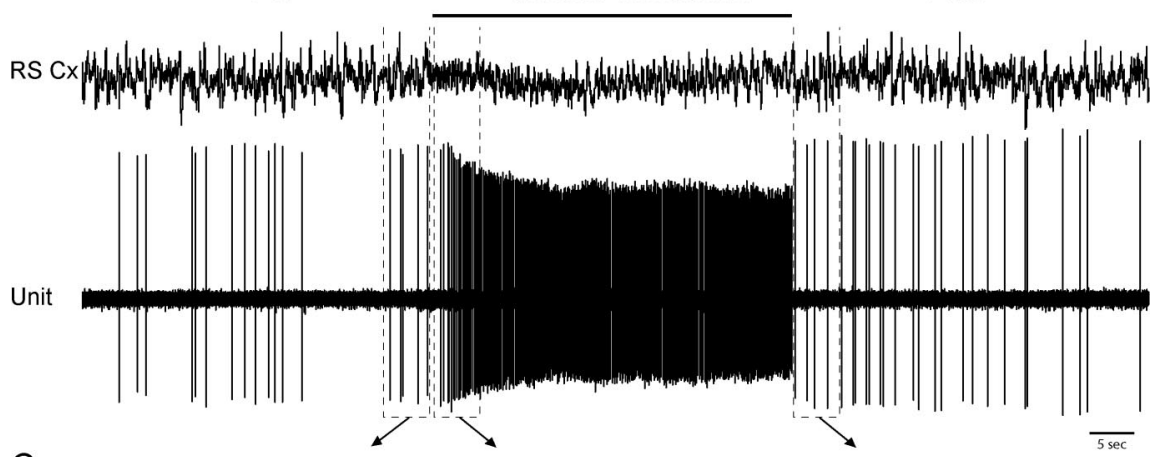

C
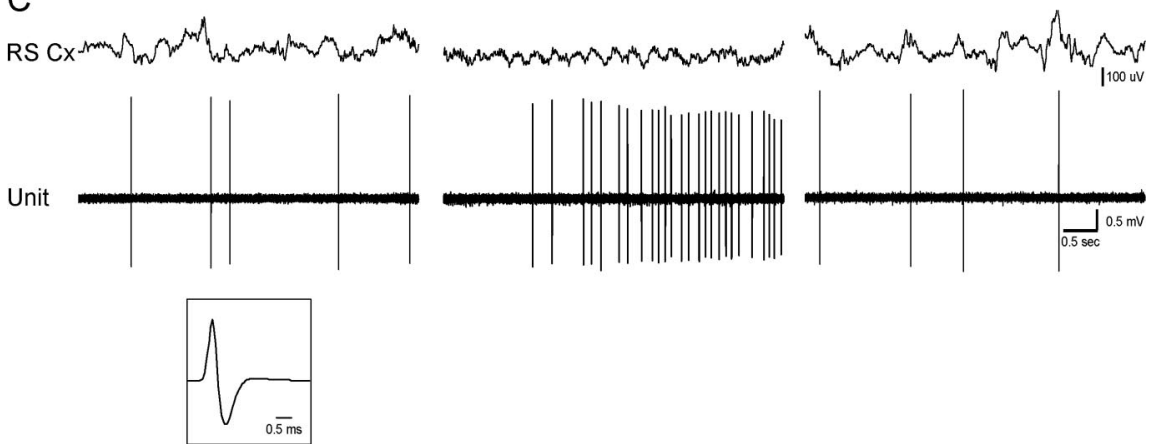

Figure 3. $\mathrm{Nb}+/ \mathrm{GAD}+$ On cell. $\boldsymbol{A}$, Nb-labeled cell (filled arrowhead, $\# A B S 78 b$ ) was negatively immunostained for VAChT (open arrowhead) and positively so for GAD (filled arrowhead), while located near other VAChT + and GAD + cells in the region (small arrows). Scale bar, $20 \mu \mathrm{m}$. The cell was situated in the LDT (largest red filled triangle) (Fig. 1, A0.1).B, C, The unit discharged at a low average rate $(0.46 \mathrm{~Hz})$ in association with irregular slow-wave activity on the EEG of the retrosplenial cortex (RSCX) before stimulation (Pre). It increased its firing markedly (to $11.49 \mathrm{~Hz}$ ) and fired tonically in association with faster cortical activity riding upon rhythmic slow (theta-like) activity during somatic stimulation. Note that the increase in unit discharge followed the change in EEG activity (by $\sim 1.22$ s). After stimulation (Post), the unit decreased its rate of firing to return to prestimulation levels in similar association with irregular slow-wave activity. Traces in $\boldsymbol{B}$ (enclosed by dashed lines) are expanded in $\boldsymbol{C}$ (arrows). The unit had a relatively short duration spike (shown in $C, 0.44$ and $1.21 \mathrm{~ms}$ at first and second zero crossings).

relatively short spike duration (Fig. $3 C)(0.42 \pm 0.02 \mathrm{~ms}$ duration to first zero crossing and $1.18 \pm 0.08 \mathrm{~ms}$ duration to second zero crossing), yet also comprised cells with longer duration spikes (supplemental Fig. 5A, available at www.jneurosci.org as supplemental material). These GABAergic neurons discharged at low rates during spontaneous irregular slow EEG activity (prestimulation) and markedly increased their firing in response to somatic stimulation and the associated cortical activation (Fig. $3 B, C$ ). Across the GABAergic On cells, the average discharge rate was significantly higher during stimulation $(7.31 \pm 1.43 \mathrm{~Hz})$ compared with prestimulation $(3.56 \pm$ $1.17 \mathrm{~Hz})$ (Table 3) and poststimulation $(3.49 \pm 1.35 \mathrm{~Hz}, p<0.05)$. During stimulation, they commonly discharged in a tonic regular to irregular manner at low to fast instantaneous firing frequencies $(6.39 \pm 1.34 \mathrm{~Hz})$ (Table 3). Some GABAergic On cells exhibited a phasic, cluster firing pattern during stimulation $(n=2$, data not Post

shown), however during neither stimulation nor prestimulation conditions was the unit discharge rhythmic or cross-correlated with slow EEG activity (data not shown). Among the GABAergic On cells which changed their activity at a discernibly different time than the EEG in response to somatic stimulation $(n=9)$, most $(n=7)$ increased their firing after the EEG activation (by $\sim 1-5 \mathrm{~s}$ ) (Fig. $3 B, C)$.

\section{$\mathrm{Nb}+/ \mathrm{GAD}+\mathrm{Off}$ cells}

The GABAergic Off cells $(n=11)$ were also heterogeneous in their morphological and physiological characteristics. They could be either small (Fig. 4A) $(n=5)$ or medium-large $(n=6)$ in size, but were predominantly bipolar, fusiform-oval-round (Fig. 4A) $(n=9)$ in shape. Like all GABAergic cells (Table 2 ), the Off cells had on average a relatively short spike duration (Fig. 4C) $(0.41 \pm 0.31 \mathrm{~ms}$ duration to first zero crossing and $1.25 \pm 0.12 \mathrm{~ms}$ to second zero crossing), yet also comprised cells with longer duration spikes (supplemental Fig. 6A, available at www. jneurosci.org as supplemental material). The Off cells discharged at slow rates during spontaneous irregular slow EEG activity (prestimulation) and ceased or markedly decreased their firing in response to somatic stimulation and the associated cortical activation (Fig. $4 B, C)$. They resumed discharge at rates similar to prestimulation following cessation of the stimulation. Across the identified GABAergic Off cells, the average discharge rate decreased significantly during stimulation $(2.14 \pm 1.18$ $\mathrm{Hz})$ compared with the prestimulation period $(4.42 \pm 1.76 \mathrm{~Hz})$ (Table 3$)$ and poststimulation period $(4.50 \pm 1.76 \mathrm{~Hz}$, $p<0.05)$. During the prestimulation condition in association with irregular slow-wave EEG activity, they commonly exhibited slow irregular tonic firing (Fig. 4C) (with average instantaneous firing frequency of $3.91 \pm 1.59 \mathrm{~Hz}$ ). Some cells displayed phasic firing in clusters of spikes $(n=4$, data not shown), and one showed rhythmic firing which was crosscorrelated with rhythmic slow theta-like activity during stimulation (data not shown). Among the GABAergic Off cells which changed their activity at a discernibly different time than the EEG in response to somatic stimulation $(n=7)$, most $(n=5)$ decreased their firing following the EEG activation (with a delay of $\sim 1-8 \mathrm{~s}$ ) (Fig. $4 B, C$ ).

\section{Noncholinergic/non-GABAergic}

\section{$(\mathrm{Nb}+/ \mathrm{VAChT}-/ \mathrm{GAD}-)$ neurons}

$\mathrm{Nb}$-labeled noncholinergic/non-GABAergic cells $(n=33)$ were heterogeneous in their properties and comprised On $(\sim 44 \%)$, Off $(\sim 42 \%)$, and No cells $(\sim 14 \%)$ (Table 1$)$, which were codis- 
tributed through the LDT, SubLDT, and MPPT. These cell subgroups did not differ significantly according to cell size or spike duration (data not shown).

VAChT-/GAD-On cells

Most noncholinergic/non-GABAergic On cells were medium-large (Fig. $5 A)(n=10)$ and the remaining small $(n=4)$. For the shape, the majority was bipolar (Fig. $5 A$ ) $(n=11)$ and the remaining multipolar $(n=3)$. They had on average a relatively short spike duration (Fig. $5 C$ ) (0.42 \pm 0.02 $\mathrm{ms}$ to first zero crossing and $1.20 \pm 0.11$ $\mathrm{ms}$ to second zero crossing), yet comprised cells with longer duration spikes (supplemental Fig. 5A, available at www.jneurosci.org as supplemental material). These neurons discharged at low rates during spontaneous irregular slow EEG activity (prestimulation) and markedly increased their rate in response to somatic stimulation and the associated cortical activation (Fig. 5B,C). They decreased and ceased firing during the poststimulation period. Across cells, the average discharge rate increased significantly during stimulation $(6.42 \pm 1.88$ $\mathrm{Hz}$ ) compared with the prestimulation period $(1.88 \pm 0.79 \mathrm{~Hz}$ ) (Table 3$)$ and poststimulation period $(3.01 \pm 1.51 \mathrm{~Hz}, p<$ $0.05)$. They generally exhibited a tonic firing pattern, either regular (Fig. 5C) or irregular $(5.24 \pm 1.78 \mathrm{~Hz}$, average instantaneous firing frequency). Some cells exhibited a phasic cluster firing pattern during prestimulation or stimulation periods ( $n=3$, data not shown), of which one was rhythmic and showed cross-correlated discharge with rhythmic slow theta-like activity during stimulation (data not shown). Of the VAChT - /GAD - On cells which changed their discharge at a discernibly different time than the EEG following somatic stimulation $(n=11)$, most $(n=8)$ started to fire before EEG activation (from $\sim 100 \mathrm{~ms}$ to $1.5 \mathrm{~s}$ ) (Fig. $5 B, C$ ). $\triangle \mathrm{Nb}+/ \mathrm{GAD}+$ "Off" cell

A
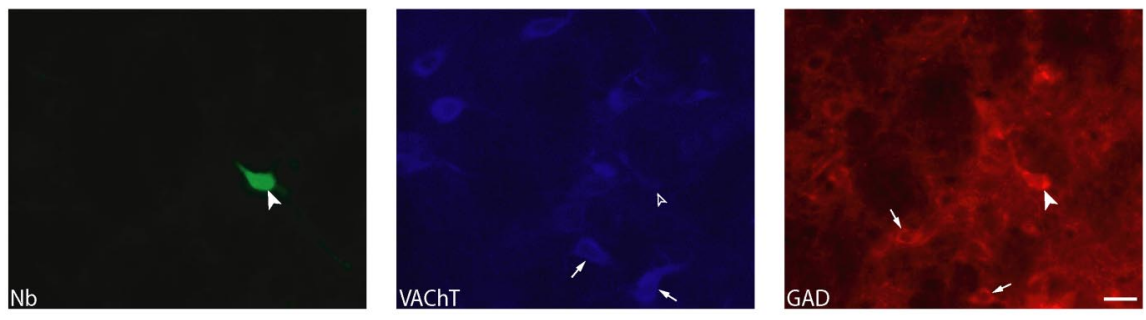

B Pre Somatic Stimulation Post
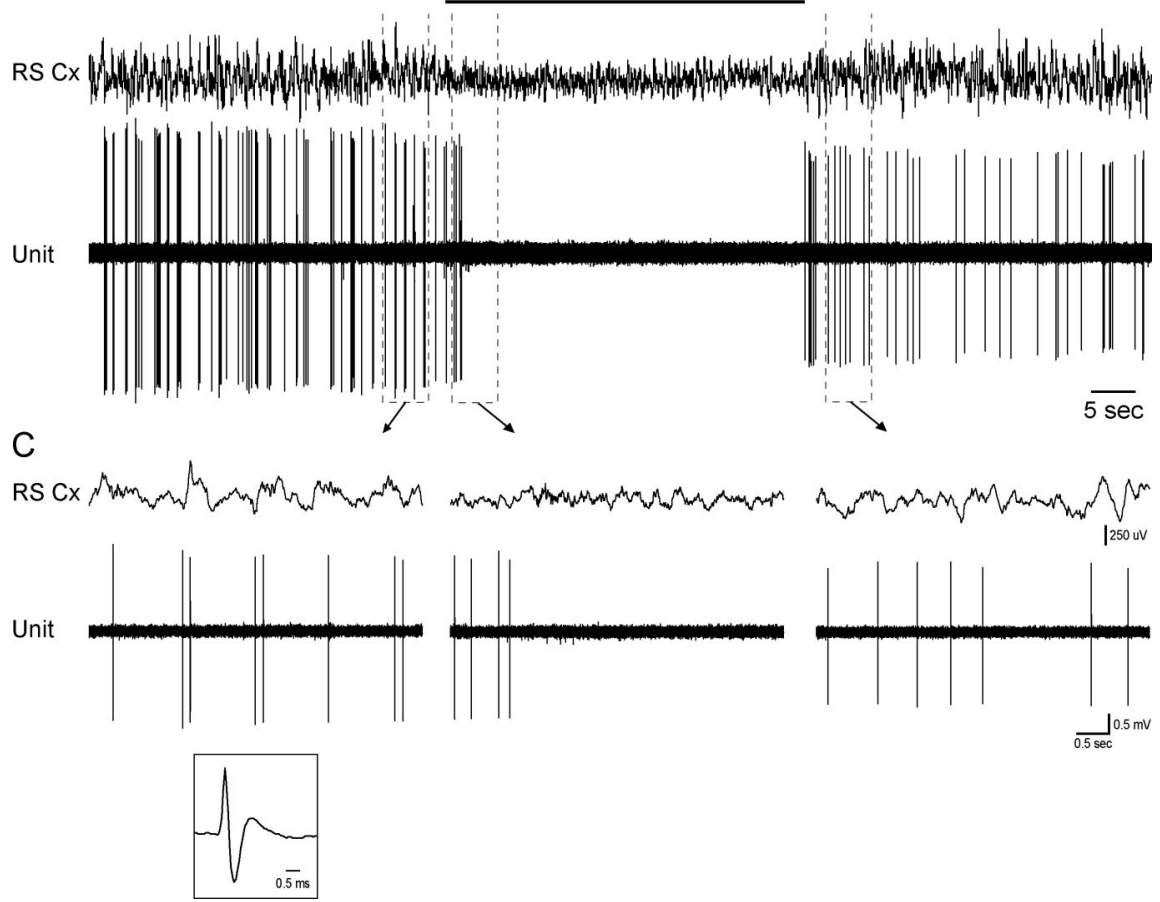

Figure 4. $\mathrm{Nb}+/ \mathrm{GAD}+$ Off cell. $A$, Nb-labeled cell (filled arrowhead, \#ABS102a) was negatively immunostained for VAChT (open arrowhead) and positively so for GAD (filled arrowhead), while located near other VAChT + and GAD + cells in the region (small arrows). Scale bar, $20 \mu \mathrm{m}$. The cell was situated in the SubLDT (largest red open triangle) (Fig. 1, A0.1). B, C, The unit discharged phasically at a moderate average rate $(2.07 \mathrm{~Hz})$ in association with irregular slow-wave activity on the EEG of the retrosplenial cortex ( $\mathrm{RS} \mathrm{C}$ ( ) before stimulation (Pre). It ceased firing in association with faster cortical activity riding upon rhythmic slow (theta-like) activity during somatic stimulation. Note that the unit ceased firing following the change in EEG activity (by $\sim 1.31 \mathrm{~s}$ ). After stimulation (Post), the unit recovered its baseline rate of firing in association with irregular slow-wave activity. Traces in $\boldsymbol{B}$ (enclosed by dashed lines) are expanded in $\boldsymbol{C}$ (arrows). The unit had a relatively short duration spike (shown in $\boldsymbol{C}, 0.35$ and $0.93 \mathrm{~ms}$ at first and second zero crossings).
VAChT-/GAD-Off cells

The VAChT - /GAD - Off cells $(n=12)$ varied in size. Like all such cells (Table 1), the Off cells could be either medium-large (Fig. $6 A)(n=7)$ or small $(n=4)$. For the shape, the majority was multipolar $(n=8)$ and the remaining bipolar (Fig. 6A) $(n=3)$. Like all VAChT $-/ G A D-($ Table 2$)$, the Off cells had on average a medium spike duration (Fig. $6 C)(0.44 \pm 0.03 \mathrm{~ms}$ to first zero crossing and $1.25 \pm 0.11 \mathrm{~ms}$ to second zero crossing) and comprised cells with short, medium, or long duration spikes (supplemental Fig. $6 A$, available at www.jneurosci.org as supplemental material). These Off neurons discharged at slow rates during spontaneous irregular slow EEG activity (prestimulation) and ceased or significantly decreased their firing in response to somatic stimulation and the associated cortical activation (Fig. $6 B, C)$. After cessation of the stimulation, they increased their firing to prestimulation discharge rate. The average discharge rate decreased significantly during stimulation $(1.98 \pm 0.86 \mathrm{~Hz})$ compared with the prestimulation period $(4.96 \pm 1.77 \mathrm{~Hz})$ (Table 3$)$ and poststimulation period $(4.77 \pm 1.64 \mathrm{~Hz}, p<0.05)$. During the prestimulation condition in association with irregular slowwave EEG activity, they commonly exhibited slow irregular tonic firing (Fig. 6C) (with average instantaneous firing frequency of $3.69 \pm 1.36 \mathrm{~Hz}$ ). Some cells exhibited a phasic cluster firing pattern ( $n=3$, data not shown), and one showed rhythmic activity during stimulation, which was cross-correlated with EEG activity (data not shown). Although only for a minority of VAChT-/ GAD - Off cells could their decrease in firing be clearly assessed in relation to the EEG following somatic stimulation $(n=5)$, most of these $(n=4)$ decreased their firing before the change in EEG activity (by $\sim 130 \mathrm{~ms}$ to $4.3 \mathrm{~s}$, data not shown). 
n $\mathrm{Nb}+$ /NAChT-/GAD- "On" cell

A
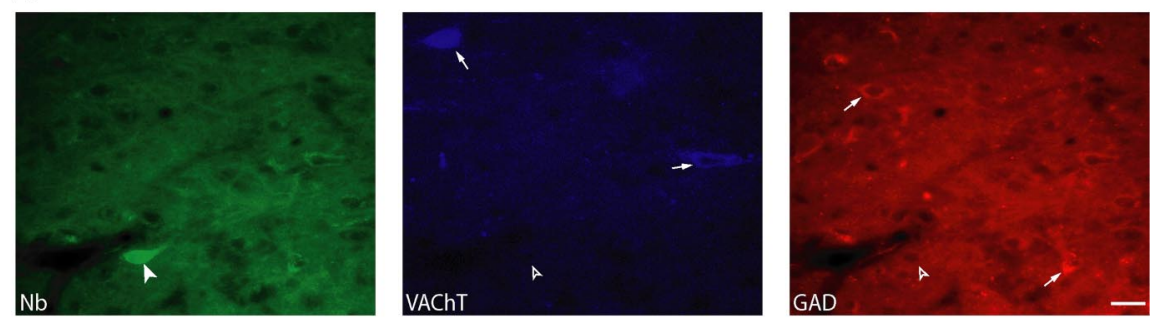

B Pre Somatic Stimulation
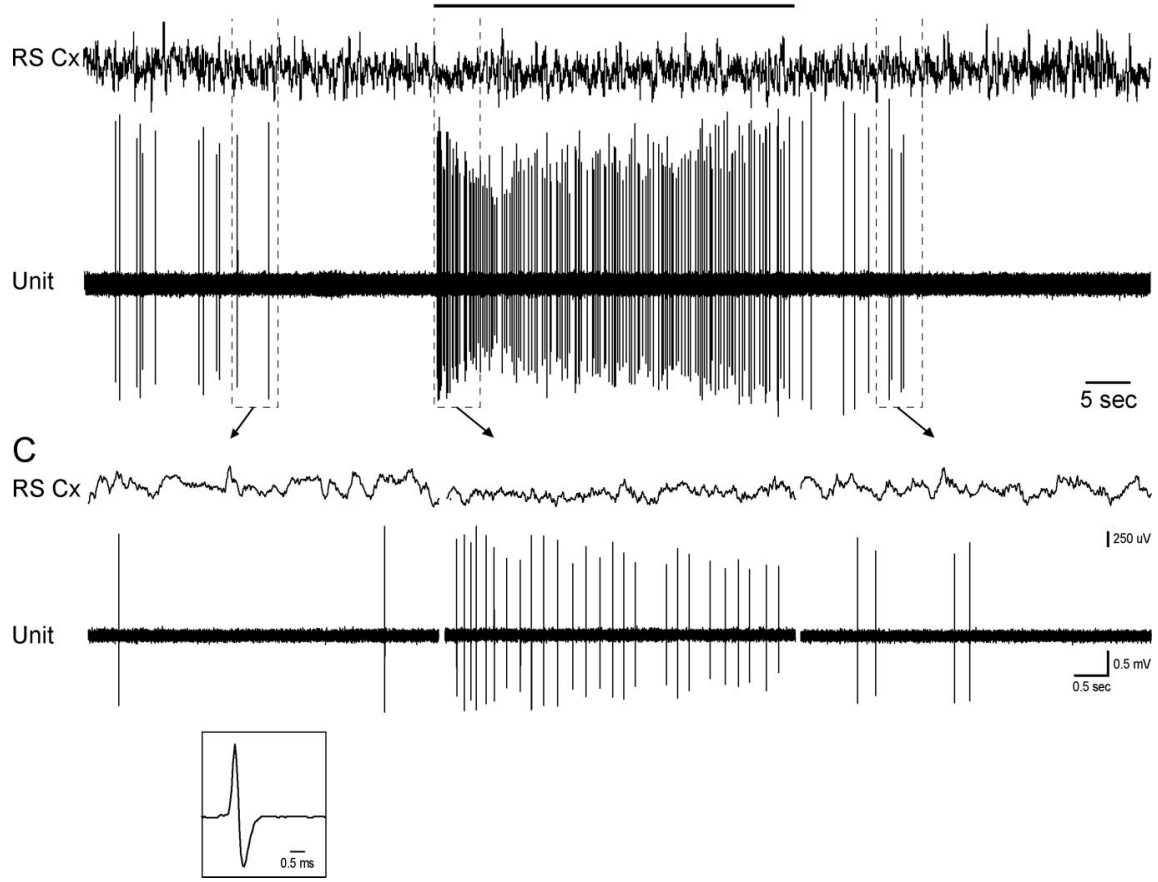

Figure 5. $\mathrm{Nb}+/ \mathrm{NAChT}-/ \mathrm{GAD}-\mathrm{On}$ cell. $\boldsymbol{A}$, Nb-labeled cell (filled arrowhead, \#ABS87c) was negatively immunostained for VAChT (open arrowhead) and for GAD (open arrowhead), while located near other VAChT + and GAD + cells in the region (small arrows). Scale bar, $20 \mu \mathrm{m}$. The cell was situated in the LDT (largest green filled square) (Fig. 1, A0.9). B, C, The unit discharged irregularly at a low average rate $(0.385 \mathrm{~Hz})$ in association with irregular slow-wave activity on the EEG of the retrosplenial cortex (RS Cx) before stimulation (Pre). It increased its firing markedly (to $3.59 \mathrm{~Hz}$ ) and fired tonically in association with faster cortical activity during somatic stimulation. Note that the increase in unit discharge preceded the change in EEG activity (by $\sim 210 \mathrm{~ms}$ ). After stimulation (Post), the unit decreased its rate back to baseline levels in association with irregular slow-wave activity. Traces in $\boldsymbol{B}$ (enclosed by dashed lines) are expanded in C (arrows). The unit had a relatively short duration spike (shown in $\mathbf{C}, 0.36$ and 0.98 $\mathrm{ms}$ at first and second zero crossings).

\section{Discussion}

This study shows that in rats under urethane anesthesia, identified cholinergic pontomesencephalic neurons discharge in association with evoked cortical activation, whereas intermingled GABAergic and noncholinergic/non-GABAergic cells discharge maximally either in association with cortical activation in a parallel manner or with cortical slow-wave activity in a reciprocal manner to the cholinergic cells. Thus while revealing the heterogeneity of codistributed cholinergic, GABAergic, and putative glutamatergic pontomesencephalic neurons, these results provide a basis for understanding the way in which these different cell groups might act in a coordinated manner to stimulate cortical activation and modulate sleep-wake states.

The electrophysiological properties of the three cell groups overlapped extensively and as such confirmed the importance of
Post

juxtacellular labeling and immunohistochemical staining of recorded cells for their unequivocal identification according to neurotransmitter phenotype. Based upon evidence in one study in anesthetized rats that neurons with long duration spikes $(0.95 \pm 0.14$, mean $\pm \mathrm{SD}$, for first zero crossing measured at zero line) were stained for nicotinamide adenine dinucleotide phosphate-diaphorase (Koyama et al., 1998), such cells were selected in studies of unanesthetized rats and cats as "presumptive" or "possibly" cholinergic cells (Kayama and Ogawa, 1987; el Mansari et al., 1989; Kayama et al., 1992). Yet, only in the present study have cells in the LDT/ PPT been randomly sampled and identified as $\mathrm{ChAT}+$, GAD+, or $\mathrm{ChAT}-/$ $\mathrm{GAD}$ - to examine the full range of spike durations for each cell type. The measurements were found to overlap extensively among cell groups here, as also previously found with intracellular recording and labeling (Takakusaki et al., 1997), such that spike duration could not be used to distinguish an individual cell as cholinergic or noncholinergic. Given a comparable overlap in average discharge rate and instantaneous firing frequency, these characteristics could also not be used alone or together with spike duration to identify individual cells as presumptive cholinergic, GABAergic, or noncholinergic/non-GABAergic.

Out of $73 \mathrm{Nb}$-labeled cells in the LDT/ SubLDT/MPPT area, 15\% were cholinergic, $40 \%$ were GABAergic and $45 \%$ were noncholinergic/non-GABAergic, proportions which correspond approximately to the relative frequency of these cell types in the LDT/PPT region (Ford et al., 1995; Wang and Morales, 2009). Based upon in situ hybridization for the vesicular glutamate transporter, VGluT2, the noncholinergic/non-GABAergic neurons would appear to be glutamatergic (Wang and Morales, 2009). Immunohistochemical staining for VGluT2 has also proven a glutamatergic identity of noncholinergic/ non-GABAergic neurons in the basal forebrain (Henny and Jones, 2008). We thus propose that the VAChT-/GAD- Nblabeled neurons recorded here in the LDT correspond to putative glutamatergic neurons.

The cholinergic LDT/SubLDT/MPPT neurons formed a homogeneous group that discharged minimally in an irregular manner $(\sim 0.5 \mathrm{~Hz})$ during irregular slow EEG activity and then in a tonic sustained manner at a moderate rate $(\sim 4 \mathrm{~Hz})$ in response to somatic stimulation in association with increased high betagamma and theta-like EEG activity. In contrast to a recent study reporting phasic modulation of cholinergic PPT neurons in association with nested gamma oscillations during slow oscillations in urethane/xylazine/ketamine-anesthetized rats (Mena-Segovia et al., 2008), the present study did not find any phasic modulation or cross-correlation with slow EEG activity of the cholinergic cell 
discharge during spontaneous, prestimulation conditions in the urethaneanesthetized rats. The presence of such phasic activity in association with gamma during slow oscillations could well be due to xylazine/ketamine anesthesia which is associated with highly synchronous slowwave activity that often develops into spike-wave seizure activity in the cortex and transmission through corticofugal projections to thalamic and subcortical networks (Timofeev et al., 1998). Moreover, ketamine is associated with anomalous high amplitude and coherent gamma activity in the cortex (Pinault, 2008), whereas urethane is associated with decreased gamma activity, similarly to natural SWS (Maloney et al., 1997; Clement et al., 2008), which can moreover be augmented as in the present study by somatic sensory stimulation. Indeed, as for the basal forebrain cholinergic neurons which have been studied both under urethane anesthesia and during natural sleep (Manns et al., 2000a; Lee et al., 2005), the LDT/PPT cholinergic neurons appear to be relatively silent in association with slow-wave activity. In contrast to the former, however, the LDT/PPT cholinergic neurons did not show any phasic, rhythmic discharge in association with theta-like EEG activity. Rhythmic bursting by basal forebrain cholinergic neurons had been shown in vitro to be driven by low threshold calcium spikes (Khateb et al., 1992), which were also found in LDT cholinergic neurons, though rarely associated with bursts (Leonard and Llinas, 1990; Kamondi et al., 1992). Here in vivo, no spike bursts were observed in cholinergic LDT/ SubLDT or MPPT cells. They would thus appear to provide a tonic slow input to their target neurons. According to the postsynaptic actions of ACh in the thalamus, their tonic discharge could change the mode of firing of thalamic cells from bursting, as occurs with spindling and slow-wave oscillations during SWS, to tonic, as occurs with fast cortical activity during waking (McCormick, 1992; Steriade, 1993). In reaction to somatic stimulation, the vast majority of cholinergic neurons started to increase their firing rate before the increase in fast cortical activity, suggesting that they are among cells of the ascending activating system that are responsible for eliciting cortical activation through excitation of thalamic, hypothalamic, and basal forebrain relays.

The GABAergic LDT/SubLDT/MPPT neurons were heterogeneous in both their physiological and morphological properties. They comprised On $(\sim 48 \%)$ and Off $(\sim 38 \%)$ cells, which respectively increased or decreased their discharge in response to somatic stimulation. On and Off GABAergic subgroups each included small, presumed locally projecting neurons and a contingent of medium-large, presumed long projecting neurons, which send their axons into the forebrain (Ford et al., 1995). The

A

B
$\mathrm{Nb}+/ \mathrm{VAChT}-/ \mathrm{GAD}-$ "Off" cell
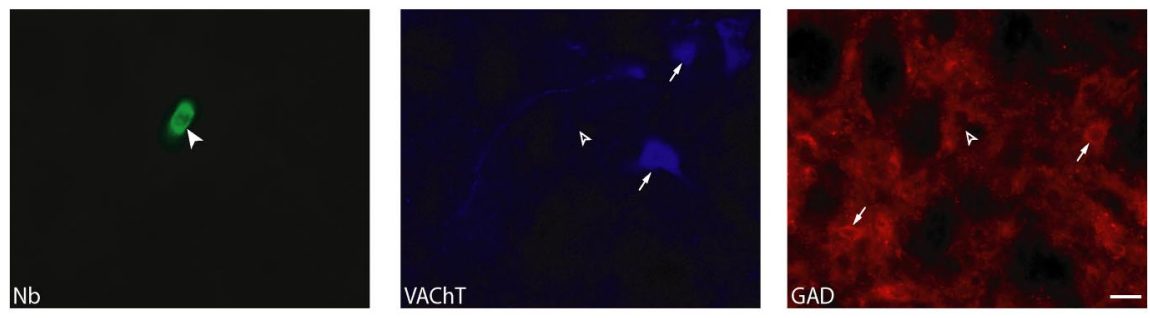
Pre Somatic Stimulation

Post
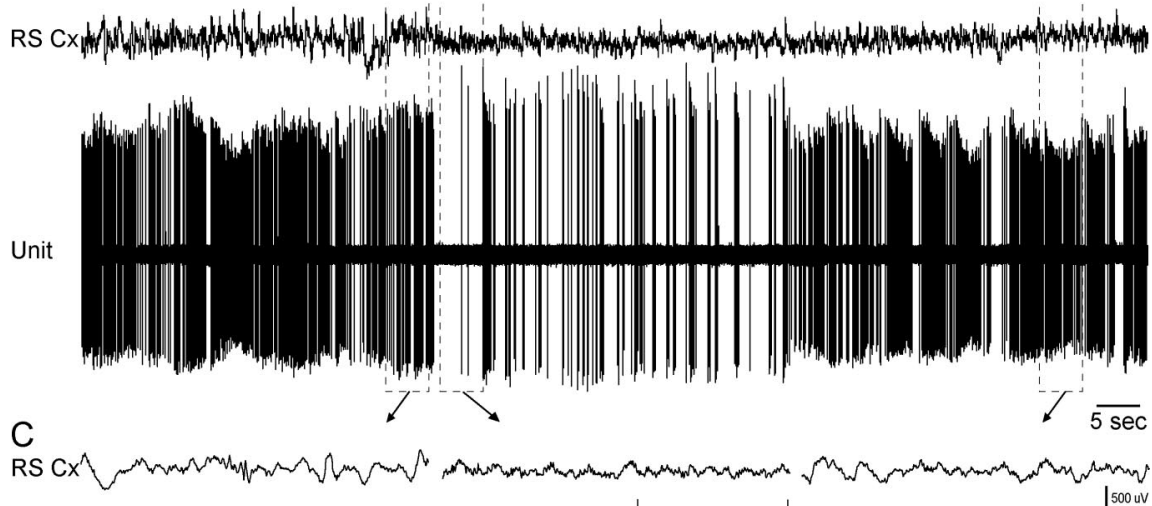
I500uv

Figure 6. $\mathrm{Nb}+/ \mathrm{VAChT}-/ \mathrm{GAD}-$ Off cell. $\boldsymbol{A}$, Nb-labeled cell (filled arrowhead, \#ABS54) was negatively immunostained for ast average rate $(13.28 \mathrm{~Hz})$ in association with irregular slow-wave activity on the EEG of the retrosplenial cortex (RS Cx) somatic stimulation. After stimulation (Post), the unit recovered its baseline rate in association with irregular slow-wave activity. Traces in $\boldsymbol{B}$ (enclosed by dashed lines) are expanded in $\boldsymbol{C}$ (arrows). The unit had a medium duration spike (shown in $\boldsymbol{C}, 0.49$ and 1.34 ms at first and second zero crossings).

GABAergic On neurons discharged and behaved in a similar manner to the cholinergic cells by increasing their rate of discharge and firing tonically during somatic stimulation. They could thus act in parallel with the cholinergic neurons either as locally projecting neurons, inhibiting other Off cells in the LDT region, or as projection neurons to other Off cells in distant regions. The GABAergic Off cells behaved in a reciprocal manner to the cholinergic cells. These GABAergic Off cells could thus normally play a role in dampening cortical activation by exerting an inhibitory influence on other neurons of the activating system. Yet, in contrast to the cholinergic neurons, most GABAergic neurons changed their rate of firing after the change in EEG evoked by somatic stimulation. This time course suggests that the GABAergic cells may be secondarily modulated by neighboring cells, including the cholinergic via release of ACh and action upon muscarinic, M1 receptors, for excitation of On cells, or M2 
receptors, for inhibition of Off cells. Different responses to ACh have been found among identified GABAergic neurons recorded in the pontine tegmentum in vitro (Brown et al., 2008). And with immunohistochemical staining, M2 receptors have been visualized upon GABAergic neurons in SubLDT and adjacent pontine tegmentum (Brischoux et al., 2008). The GABAergic neurons could also be influenced by the local glutamatergic neurons (below) or by other distant neurons involving feedback from the thalamus, hypothalamus, and/or basal forebrain.

Like the GABAergic neurons, the putative glutamatergic neurons were also heterogeneous in their properties and response to somatic stimulation, thus also comprising On ( $49 \%)$ and Off $(\sim 35 \%)$ cell groups, which similarly varied in size and shape. In this case, however, the response of the putative glutamatergic neurons generally preceded the changes in cortical activation, as it did for the cholinergic cells. Indeed, the glutamatergic On cells could act in parallel to the cholinergic cells and form an important contingent of long ascending projections from the LDT/PPT into the forebrain (Paré et al., 1988; Jones and Cuello, 1989; Rasmusson et al., 1994; Ford et al., 1995). The putative glutamatergic On and Off cells could also control the local GABAergic On and Off cells (above).

Given the impossibility of identifying recorded cells as cholinergic, GABAergic, or putative glutamatergic according to discharge properties here in anesthetized animals, it is also not possible to postulate that they correspond to cells previously recorded in unanesthetized animals and characterized as discharging in particular sleep-wake states. Nonetheless, given the homogeneous response profile of cholinergic LDT/SubLDT/ MPPT neurons found here, it can be stated that these cells discharge in association with cortical activation and thus could do so during both waking and PS, as was established to be the case for identified cholinergic neurons in the basal forebrain (Manns et al., 2000a; Lee et al., 2005). Indeed, ACh release in the thalamus, which would arise largely from the brainstem cholinergic neurons, is low during SWS and high during both waking and PS in association with cortical activation (Williams et al., 1994). In the $\mathrm{LDT} / \mathrm{PPT}$ region of both cat and rat, Wake-PS active cells were previously postulated to be presumptive or possibly cholinergic neurons (el Mansari et al., 1989; Steriade et al., 1990a; Kayama et al., 1992). However, our results would indicate that such Wake-PS cells likely also include noncholinergic cells. Possibly cholinergic neurons were also proposed to be most active during PS and relatively silent during waking (Kayama et al., 1992). Yet, such PS-active cells also increased their discharge during SWS relative to waking (Steriade et al., 1990a; Kayama et al., 1992). They would thus more likely correspond to noncholinergic cells which were found here to have a higher rate of discharge during spontaneous irregular slow activity and thus to GABAergic or putative glutamatergic Off neurons. Such Off cells could thus gradually increase their rate of firing during sleep to fire maximally during PS in association with decreasing muscle tone in the natural sleep cycle. GABAergic Off cells could progressively inhibit other surrounding neurons during sleep, such as the serotonergic or noradrenergic cells which discharge during waking and turn off during sleep to be silent during PS (McGinty and Harper, 1976; Aston-Jones and Bloom, 1981; Maloney et al., 1999). Discharging in parallel but also in the lead, glutamatergic Off cells may normally excite these GABAergic Off, postulated sleep-active cells in the region. Cells classified as Wake-active, which discharge during wake and not during SWS or PS (Kayama et al., 1992), might include some of the putative glutamatergic and GABAergic On cells recorded here. Clearly, future studies applying recording with juxtacellular labeling in naturally sleeping-waking rats will be necessary to elucidate the precise roles of these cell groups in sleep-wake states. The present results indicate that cholinergic, GABAergic, and putative glutamatergic neurons can function in parallel or reciprocal manners to modulate cortical activity and behavioral state across the sleep-waking cycle.

\section{References}

Amatruda TT 3rd, Black DA, McKenna TM, McCarley RW, Hobson JA (1975) Sleep cycle control and cholinergic mechanisms: differential effects of carbachol injections at pontine brain stem sites. Brain Res 98:501-515.

Aston-Jones G, Bloom FE (1981) Activity of norepinephrine-containing locus coeruleus neurons in behaving rats anticipates fluctuations in the sleep-waking cycle. J Neurosci 1:876-886.

Brischoux F, Mainville L, Jones BE (2008) Muscarinic-2 and orexin-2 receptors on GABAergic and other neurons in the rat mesopontine tegmentum and their potential role in sleep-wake state control. J Comp Neurol 510:607-630.

Brown RE, McKenna JT, Winston S, Basheer R, Yanagawa Y, Thakkar MM, McCarley RW (2008) Characterization of GABAergic neurons in rapideye-movement sleep controlling regions of the brainstem reticular formation in GAD67-green fluorescent protein knock-in mice. Eur J Neurosci 27:352-363.

Clement EA, Richard A, Thwaites M, Ailon J, Peters S, Dickson CT (2008) Cyclic and sleep-like spontaneous alternations of brain state under urethane anaesthesia. PLoS ONE 3:e2004.

el Mansari M, Sakai K, Jouvet M (1989) Unitary characteristics of presumptive cholinergic tegmental neurons during the sleep-waking cycle in freely moving cats. Exp Brain Res 76:519-529.

Ford B, Holmes CJ, Mainville L, Jones BE (1995) GABAergic neurons in the rat pontomesencephalic tegmentum: codistribution with cholinergic and other tegmental neurons projecting to the posterior lateral hypothalamus. J Comp Neurol 363:177-196.

Gillin JC, Sitaram N (1984) Rapid eye movement (REM) sleep: cholinergic mechanisms. Psychol Med 14:501-506.

Hallanger AE, Levey AI, Lee HJ, Rye DB, Wainer BH (1987) The origins of cholinergic and other subcortical afferents to the thalamus in the rat. J Comp Neurol 262:105-124.

Henny P, Jones BE (2008) Projections from basal forebrain to prefrontal cortex comprise cholinergic, GABAergic and glutamatergic inputs to pyramidal cells or interneurons. Eur J Neurosci 27:654-670.

Jones BE (1990) Immunohistochemical study of choline acetyl transferaseimmunoreactive processes and cells innervating the pontomedullary reticular formation. J Comp Neurol 295:485-514.

Jones BE (1993) The organization of central cholinergic systems and their functional importance in sleep-waking states. Prog Brain Res 98:61-71.

Jones BE (2004) Paradoxical REM sleep promoting and permitting neuronal networks. Arch Ital Biol 142:379-396.

Jones BE, Cuello AC (1989) Afferents to the basal forebrain cholinergic cell area from pontomesencephalic_catecholamine, serotonin, and acetylcholine-neurons. Neuroscience 31:37-61.

Jones BE, Yang TZ (1985) The efferent projections from the reticular formation and the locus coeruleus studied by anterograde and retrograde axonal transport in the rat. J Comp Neurol 242:56-92.

Kamondi A, Williams JA, Hutcheon B, Reiner PB (1992) Membrane properties of mesopontine cholinergic neurons studied with the whole-cell patch-clamp technique: implications for behavioral state control. J Neurophysiol 68:1359-1372.

Karczmar AG, Longo VG, de Carolis AS (1970) A pharmacological model of paradoxical sleep: the role of cholinergic and monoamine systems. Physiol Behav 5:175-182.

Kayama Y, Ogawa T (1987) Electrophysiology of ascending, possibly cholinergic neurons in the rat laterodorsal tegmental nucleus: comparison with monoamine neurons. Neurosci Lett 77:277-282.

Kayama Y, Ohta M, Jodo E (1992) Firing of 'possibly' cholinergic neurons in the rat laterodorsal tegmental nucleus during sleep and wakefulness. Brain Res 569:210-220.

Khateb A, Mühlethaler M, Alonso A, Serafin M, Mainville L, Jones BE (1992) Cholinergic nucleus basalis neurons display the capacity for rhythmic 
bursting activity mediated by low threshold calcium spikes. Neuroscience 51:489-494.

Koyama Y, Honda T, Kusakabe M, Kayama Y, Sugiura Y (1998) In vivo electrophysiological distinction of histochemically identified cholinergic neurons using extracellular recording and labelling in rat laterodorsal tegmental nucleus. Neuroscience 83:1105-1112.

Lee MG, Hassani OK, Alonso A, Jones BE (2005) Cholinergic basal forebrain neurons burst with theta during waking and paradoxical sleep. J Neurosci 25:4365-4369.

Leonard CS, Llinas RR (1990) Electrophysiology of mammalian pedunculopontine and laterodorsal tegmental neurons in vitro: implications for the control of REM sleep. In: Brain cholinergic systems (Steriade M, Biesold D, eds), pp 205-223. New York: Oxford UP.

Maloney KJ, Cape EG, Gotman J, Jones BE (1997) High-frequency gamma electroencephalogram activity in association with sleep-wake states and spontaneous behaviors in the rat. Neuroscience 76:541-555.

Maloney KJ, Mainville L, Jones BE (1999) Differential c-Fos expression in cholinergic, monoaminergic and GABAergic cell groups of the pontomesencephalic tegmentum after paradoxical sleep deprivation and recovery. J Neurosci 19:3057-3072.

Manns ID, Alonso A, Jones BE (2000a) Discharge properties of juxtacellularly labeled and immunohistochemically identified cholinergic basal forebrain neurons recorded in association with the electroencephalogram in anesthetized rats. J Neurosci 20:1505-1518.

Manns ID, Alonso A, Jones BE (2000b) Discharge profiles of juxtacellularly labeled and immunohistochemically identified GABAergic basal forebrain neurons recorded in association with the electroencephalogram in anesthetized rats. J Neurosci 20:9252-9263.

Manns ID, Alonso A, Jones BE (2003) Rhythmically discharging basal forebrain units comprise cholinergic, GABAergic, and putative glutamatergic cells. J Neurophysiol 89:1057-1066.

McCormick DA (1992) Cellular mechanisms underlying cholinergic and noradrenergic modulation of neuronal firing mode in the cat and guinea pig dorsal lateral geniculate nucleus. J Neurosci 12:278-289.

McGinty DJ, Harper RM (1976) Dorsal raphe neurons: depression of firing during sleep in cats. Brain Res 101:569-575.

Mena-Segovia J, Sims HM, Magill PJ, Bolam JP (2008) Cholinergic brainstem neurons modulate cortical gamma activity during slow oscillations. J Physiol 586:2947-2960.

Mesulam MM, Mufson EJ, Wainer BH, Levey AI (1983) Central cholinergic pathways in the rat: an overview based on an alternative nomenclature (Ch1-Ch6). Neuroscience 10:1185-1201.

Mitani A, Ito K, Hallanger AE, Wainer BH, Kataoka K, McCarley RW (1988) Cholinergic projections from the laterodorsal and pedunculopontine teg- mental nuclei to the pontine gigantocellular tegmental field in the cat. Brain Res 451:397-402.

Paré D, Smith Y, Parent A, Steriade M (1988) Projections of brainstem core cholinergic and non-cholinergic neurons of cat to intralaminar and reticular thalamic nuclei. Neuroscience 25:69-86.

Pinault D (1996) A novel single-cell staining procedure performed in vivo under electrophysiological control: morpho-functional features of juxtacellularly labeled thalamic cells and other central neurons with biocytin or Neurobiotin. J Neurosci Methods 65:113-136.

Pinault D (2008) N-methyl d-aspartate receptor antagonists ketamine and MK-801 induce wake-related aberrant gamma oscillations in the rat neocortex. Biol Psychiatry 63:730-735.

Rasmusson DD, Clow K, Szerb JC (1994) Modification of neocortical acetylcholine release and electroencephalogram desynchronization due to brainstem stimulation by drugs applied to the basal forebrain. Neuroscience 60:665-677.

Semba K, Reiner PB, Fibiger HC (1990) Single cholinergic mesopontine tegmental neurons project to both the pontine reticular formation and the thalamus in the rat. Neuroscience 38:643-654.

Steriade M (1993) Cholinergic blockage of network- and intrinsically generated slow oscillations promotes waking and REM sleep activity patterns in thalamic and cortical neurons. Prog Brain Res 98:345-355.

Steriade M (2004) Acetylcholine systems and rhythmic activities during the waking-sleep cycle. Prog Brain Res 145:179-196.

Steriade M, Datta S, Paré D, Oakson G, Curró Dossi RC (1990a) Neuronal activities in brain-stem cholinergic nuclei related to tonic activation processes in thalamocortical systems. J Neurosci 10:2541-2559.

Steriade M, Paré D, Datta S, Oakson G, Curró Dossi R (1990b) Different cellular types in mesopontine cholinergic nuclei related to pontogeniculo-occipital waves. J Neurosci 10:2560-2579.

Takakusaki K, Shiroyama T, Kitai ST (1997) Two types of cholinergic neurons in the rat tegmental pedunculopontine nucleus: electrophysiological and morphological characterization. Neuroscience 79:1089-1109.

Timofeev I, Grenier F, Steriade M (1998) Spike-wave complexes and fast components of cortically generated seizures. IV. Paroxysmal fast runs in cortical and thalamic neurons. J Neurophysiol 80:1495-1513.

Wang HL, Morales M (2009) Pedunculopontine and laterodorsal tegmental nuclei contain distinct populations of cholinergic, glutamatergic and GABAergic neurons in the rat. Eur J Neurosci 29:340-358.

Webster HH, Jones BE (1988) Neurotoxic lesions of the dorsolateral pontomesencephalic tegmentum-cholinergic cell area in the cat. II. Effects upon sleep-waking states. Brain Res 458:285-302.

Williams JA, Comisarow J, Day J, Fibiger HC, Reiner PB (1994) Statedependent release of acetylcholine in rat thalamus measured by in vivo microdialysis. J Neurosci 14:5236-5242. 